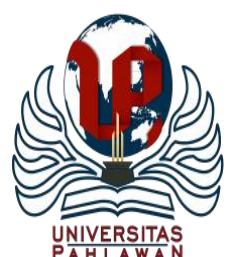

Jurnal Abdidas Volume 2 Nomor 6 Tahun 2021 Halaman 1392 - 1401

JURNAL ABDIDAS

http://abdidas.org/index.php/abdidas

\title{
Krisis UNBK: Mentoring Guru dalam Menyelesaikan, Menyusun dan Mengembangkan Soal Kategori HOTS untuk Meningkatkan Hasil Ujian Nasional Di Dataran Tinggi Gayo
}

\author{
Lola Mandasari ${ }^{1}$, Septia Wahyuni ${ }^{2}$ \\ Institut Agama Islam Negeri Takengon, Indonesia ${ }^{1,2}$ \\ E-mail : $\underline{\text { lolamandasari@gmail.com }}{ }^{1} \underline{\text { septiawahyuni86@gmail.com }}^{2}$
}

\begin{abstract}
Abstrak
Pelatihan ini bertujuan untuk memberikan gambaran kepada guru Matematika SMA/MA sederajat tentang cara Menyusun, menyelesaikan dan mengembangkan soal Matematika kategori HOTS. Adapaun peserta pelatihan ini berjumlah 40 orang guru matematika SMA/MA sederajat di kabupaten Aceh Tengah. Tahapan pelaksanaan pelatihan dimulai dari pelaksanaan pre-test, pelaksanaan seminar yang diisi oleh 3 orang narasumber kemudian peserta pelatihan praktik penyusunan soal matematika kategori HOTS dan tahap akhir peserta menjawab soal post-test. Dari hasil pelatihan peserta memiliki semangat yang tinggi dalam pelaksanaan pelatihan, dari hasil pre-test peserta masih memiliki nilai yang cukup rendah, kemudian setelah dilaksanakan seminar tentang soal kategori HOTS peserta mulai memahami ciri soal kategori HOTS. Soal yang disusun juga sangat variative, dan nilai postes meningkat meskipun tidak begitu signifikan.
\end{abstract}

Kata kunci: mentoring, soal HOTS, ujian nasional

\begin{abstract}
This training aims to provide an overview to high school / MA Mathematics teachers on how to compose, solve and develop HOTS category Mathematics questions. The participants for this training were 40 high school/MA mathematics teachers in the district of Central Aceh. The stages of the training implementation started from the pre-test implementation, the seminar was filled by 3 resource persons, then the participants of the practical training on the preparation of the HOTS category mathematics questions and the final stage of the participants answering the post-test questions. From the results of the training the participants had high enthusiasm in the implementation of the training, from the results of the pre-test the participants still had a fairly low score, then after the seminar was held on the HOTS category questions, the participants began to understand the characteristics of the HOTS category questions. The questions that were prepared were also very varied, and the posttest scores increased, although not significantly.
\end{abstract}

Keywords: mentoring, HOTS questions, national exams

Copyright (c) 2021 Lola Mandasari, Septia Wahyuni

$\triangle$ Corresponding author

Address : IAIN Takengon Jl. Yos Sudarso No. 10 Takengon

Email : lolamandasari@gmail.com

DOI $\quad$ : https://doi.org/10.31004/abdidas.v2i6.495

ISSN 2721-9224 (Media Cetak)

ISSN 2721- 9216 (Media Online) 
1393 Krisis UNBK: Mentoring Guru dalam Menyelesaikan, Menyusun dan Mengembangkan Soal Kategori HOTS untuk Meningkatkan Hasil Ujian Nasional Di Dataran Tinggi Gayo - Lola Mandasari, Septia Wahyuni

DOI: https://doi.org/10.31004/abdidas.v2i6.495

\section{PENDAHULUAN}

Pendidikan merupakan ujung tombak majunya suatu negara, setiap negara memiliki cara yang berbeda untuk mengukur keberhasilan system pendidikannya. Di Indonesia, sejak tahun 2011 Ujian nasional mulai dilaksanakan. Ujian nasional merupakan suatu sistem evaluasi standar secara nasional untuk pendidikan dasar dan menengah untuk persamaan mutu tingkat pendidikan antar daerah yang dilakukan oleh Pusat Penilaian Pendidikan, Depdiknas di Indonesia (Wikipedia, 2019). Dan salah satu tujuan dari pelaksanaan ujian nasional adalah untuk mengukur pencapaian kompetensi lulusan pada mata pelajaran tertentu secara nasional dengan mengacu pada Standar Kompetensi Lulusan (Pendidikan, 2018). Namun, sampai sekarang hasil ujian nasional sendiri tidak dapat dikatakan memuaskan.

Salah satu daerah yang menarik perhatian adalah Aceh, untuk jenjang SMP/MTs dan SMA/MA pada tahun 2017 Aceh tidak termasuk kedalam 5 besar daerah dengan nilai UN terendah secara nasional, namun pada 2018 Aceh mendapat posisi terendah pertama baik di jenjang SMP/MTs maupun SMA/MA, dan pada tahun berikutnya juga masih bisa dikatakan menempati posisi yang sama pada tahun sebelumnya, hanya mendapat selisih 0,03 dari posisi terendah untuk jenjang SMP/MTs dan selisih 0,68 untuk jenjang SMA/MA. Berikut grafik nilai UN Mata Pelajaran Matematika untuk Provinsi Aceh.

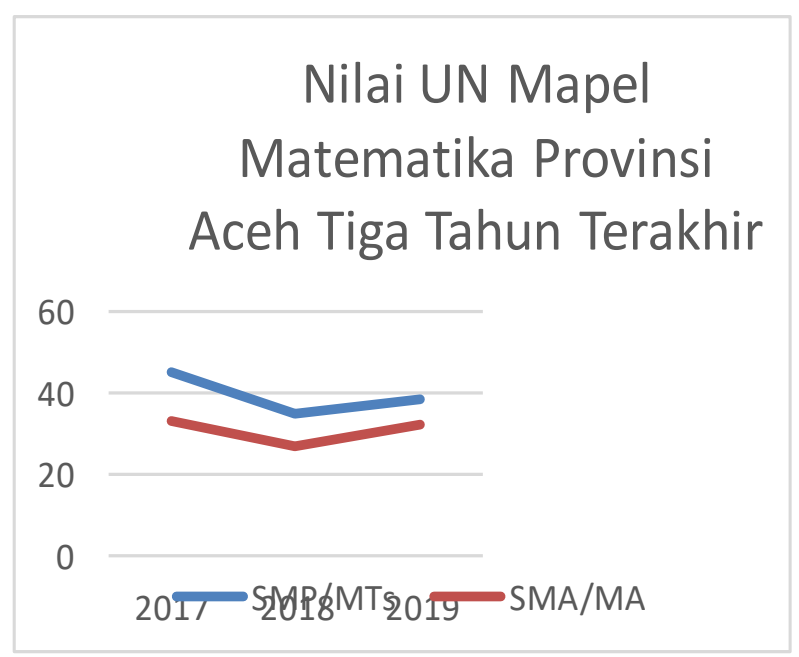

Gambar 1. Nilai UN Prov Aceh Tengah Tiga Tahun Terakhir

Dari grafik diatas terlihat bahwa pada tahun 2018 nilai rata-rata ujian nasional mata pelajaran matematika di jenjang SMP/MTs turun sejauh 10,11 dari tahun sebelumnya. Begitu juga halnya dengan nilai rata-rata UN mata pelajaran matematika pada jenjang SMA/MA turun sejauh 6,52. Pada tahun 2019 meningkat sejauh 3,63 untuk jenjang SMP/MTs, 5.49 untuk jenjang SMA/MA. Namun peningkatan ini masih jauh dari rata-rata nasional. Banyak hal yang dapat menyebabkan hal ini terjadi, diantaranya adalah faktor internal dari siswa dan faktor eksternal yaitu : kualitas dan kemampuan guru, proses belajar mengajar di sekolah, lingkungan belajar di sekolah dan rumah, kurikulum, fasilitas/sarana dan prasarana yang dimiliki dan digunakan siswa di sekolah maupun di rumah, assesmen yang digunakan, termasuk situasi dan kondisi pada saat ujian berlangsung, lingkungan fisik tempat ujian berlangsung, dan juga masalah teknis berkenaan dengan cara mengisi lembar jawaban dan proses 
1394 Krisis UNBK: Mentoring Guru dalam Menyelesaikan, Menyusun dan Mengembangkan Soal Kategori HOTS untuk Meningkatkan Hasil Ujian Nasional Di Dataran Tinggi Gayo - Lola Mandasari, Septia Wahyuni

DOI: https://doi.org/10.31004/abdidas.v2i6.495

pemeriksaan lembar jawaban. Namun, hal yang paling menarik perhatian adalah assesmen yang digunakan pada dua tahun terakhir, tepatnya soal UN yang digunakan pada tahun 2018 dan 2019 dimana pada saat yang bersamaan nilai UN di provinsi Aceh menurun drastis pada tahun tersebut. Ada perubahan yang mencolok pada bahan soal UN di tahun 2018 dan 2019 yaitu penambahan soal HOTS pada UNBK. Dimana, penambahan soal HOTS pada soal UN ini masih menjadi polemik di dunia pendidikan sampai saat ini.

Pada tahun 2018 Kementerian Pendidikan dan Kebudayaan (Kemendikbud) mulai menambahkan soal-soal yang disusun dengan instrumen Higher Order Thinking Skill (HOTS). Soal HOTS harus mencakup analisis, evaluasi, dan mencipta. Tiga tahap tersebut adalah tahapan tertinggi pendidikan dalam taksonomi Bloom. Menurut Benjamin Bloom, seorang ahli di dunia pendidikan terdapat beberapa tujuan pendidikan, yaitu menghafal, memahami, mengaplikasikan, menganalisis, mengevaluasi, dan mencipta. Untuk dapat menyelesaikan masalah kompleks, seorang siswa harus memiliki kemampuan berpikir tingakt tinggi. Adapun tujuan penambahan soal HOTS pada ujian nasional adalah untuk melatih siswa menghadapi tantangan zaman yang semakin kompleks dan meningkatkan kualitas soal Ujian Nasional (UN), Mendikbud Muhadjir Effendy menginginkan siswa lulusan sekolah menengah secara berlahan bisa memiliki kemampuan yang akan menjadi standar hingga tahun 2025 (EFFENDY, n.d.). Menurut Kepala Balitbang
Kemendikbud Totok Suprayitno, jumlah soal HOTS yang terdapat pada UN pada tahun 2018 dan 2019 adalah sama, jumlah soal untuk penalaran 10\%-15\%, jumlah soal untuk aplikasi 50\%-60 \% dan jumlah soal untuk pengetahuan dan pemahaman sekitar 25\%-30\% (Suprayitno, 2019c). Namun tidak begitu halnya dengan tahun depan, hal ini sesuai dengan pernyataan Kepala Badan Penelitian dan Pengembangan Ir. Totok Suprayitno,Ph.D, bahwa tahun depan soal UNBK akan didominasi oleh soal jenis higher order thinking skills (HOTS), kualitas UN juga turut ditingkatkan dengan target $100 \%$ berbasis komputer. Penambahan soal HOTS pada UNBK tahun 2020 karena mempertimbangkan hasil evaluasi UNBK tahun 2019 yang mengalami peningkatan dari tahun sebelumnya (Suprayitno, 2019b).

Hal ini akan menjadi momok yang menakutkan bagi siswa mengingat masih banyak siswa yang mengalami kesulitan dalam mengerjakan soal HOTS. Hal ini terbukti dari rendahnya kenaikan nilai rata-rata $\mathrm{UN}$ mata pelajaran matematika di 2019, dengan komposisi soal dan tingkat kesulitan yang sama pada tahun sebelumnya sudah selayaknya nilai UN yang diperoleh juga meningkat lebih tinggi . keadaan ini mengindikasikan bahwa belum ada kemajuan dari segi kemampuan siswa dan sebagian besar siswa masih belum terbiasa menyelesaikan soal HOTS. Hal ini sesuai dengan hasil Programme for International Student Assessment (PISA) 2016, sebanyak 70 persen siswa Indonesia ternyata tidak dapat menjawab soal berkategori Higher Order 
1395 Krisis UNBK: Mentoring Guru dalam Menyelesaikan, Menyusun dan Mengembangkan Soal Kategori HOTS untuk Meningkatkan Hasil Ujian Nasional Di Dataran Tinggi Gayo - Lola Mandasari, Septia Wahyuni

DOI: https://doi.org/10.31004/abdidas.v2i6.495

Thinking Skill (HOTS), saat ini siswa Indonesia masih berada pada berpikir tingkat rendah atau Lower Order Thinking Skill (LOTS) (Shihab, 2019). Dan Kepala Badan Penelitian dan Pengembangan Kemendikbud Totok Suprayitno mengatakan, dari hasil UN 2018 diketahui bahwa sebanyak $40 \%$ siswa mengalami kesulitan saat menyelesaikan soal UN (Suprayitno, 2019a). Dari kedua pernyataan di atas dapat disimpulkan bahwa kemampuan siswa dalam menjawab soal HOTS masih tergolong rendah, dan perlu adanya usaha untuk meningkatkan dan mengejar ketertinggalan.

Salah satu usaha yang dapat dilakukan oleh pemerintah pusat dan daerah adalah mengenalkan dan mendekatkan siswa dengan soal soal HOTS. Dan pihak yang paling dianggap mampu dan bertanggung jawab untuk melakukan pengenalan, pendekatan dan pembiasaan soal-soal HOTS tersebut dengan siswa adalah guru. Siswa harus terbiasa menyelesaikan soal HOTS di setiap materi pelajaran yang mereka peroleh di sekolah. Dengan pembiasaan tersebut mereka akan lebih mudah menyelesaian soal soal HOTS dengan berbagai variasi dan tingkat kesulitan yang berbeda, bahkan mereka akan mampu menemukan trik tersendiri untuk menyelesaikan soal-soal tersebut. Sehingga saat UN berlangsung, soal HOTS tersebut tidak lagi dianggap sebagai sesuatu yang menghawatirkan. Namun, yang menjadi kendala saat ini adalah sebagian besar guru belum mampu memahami dan menguasai cara penyusunan, penyelesaian dan pengembangan soal HOTS. Kendala ini terjadi disebabkan oleh sosialisasi dan pelatihan yang dilakukan oleh pemerintah masih kurang merata dan maksimal di berbagai daerah di Indonesia.

Menurut Direktur Jenderal (Dirjen) Pendidikan Dasar dan Menengah (Dikdasmen) Kemendikbud Hamid Muhammad, soal ujian yang membutuhkan kemampuan berpikir tingkat tinggi atau High Order Thinking Skill (HOTS) bukan hal yang baru, guru-guru SMA sudah diberikan pelatihan sejak tahun 2016. Kendati begitu, beliau mengakui pelatihan soal HOTS belum dilakukan secara merata dan optimal. Selama ini, pelatihan guru-guru dilakukan secara paralel dan dimulai dari tingkat nasional, lalu ke provinsi hingga ke kabupaten atau kota (Muhammad, 2019). Hal ini juga sesuai dengan observasi awal yang telah dilakukan di beberapa sekolah di kabupaten Aceh Tengah, guru di sekolah tersebut menyatakan masih kesulitan dalam mengenalkan soal-soal HOTS kepada siswa, mereka juga memberi pernyataan bahwa mereka belum pernah mendapatkan pelatihan mengenai soal HOTS.

Kabupaten Aceh Tengah merupakan salah satu kabupaten yang berada di provinsi Aceh. Kabupaten Aceh Tengah merupakan salah satu daerah yang berada pada kawasan Dataran Tinggi Gayo. Nilai rata- rata UN mata pelajaran matematika pada jenjang SMA/MA jurusan IPA yang diperoleh sekolah pada kabupaten ini berada di bawah rata-rata nilai UN secara nasional. Dengan dilaksanakannya kegiatan mentoring guru terhadap pengenalan soal HOTS diharapkan dapat meningkatkan kemampuan guru dalam menyelesaikan, menyusun dan mengembangkan soal HOTS sehingga dapat mendorong 
1396 Krisis UNBK: Mentoring Guru dalam Menyelesaikan, Menyusun dan Mengembangkan Soal Kategori HOTS untuk Meningkatkan Hasil Ujian Nasional Di Dataran Tinggi Gayo - Lola Mandasari, Septia Wahyuni

DOI: https://doi.org/10.31004/abdidas.v2i6.495

kemampuan siswa dalam menyelesaikan soal HOTS pada UNBK. Selain itu pelaksanaan pelatihan ini bertujuan untuk meningkatkan nilai UNBK di jenjang SMP/MTs dan SMA/MA di Dataran Tinggi Gayo.

\section{METODE}

Model pelaksanaan yang digunakan dalam pengabdian ini adalah mentoring dalam kegiatan seminar, pelatihan dan FGD, peserta diberikan penjelasan tentang materi HOTS dan kemudian diberikan tugas kerja untuk melakukan penyelesaian, penyusunan dan pengembangan soal HOTS, kemudian para mentee akan dikumpulkan dalam beberapa kelompok kecil untuk melakukan diskusi mengenai soal-soal yang telah diselesaikan, disusun dan dikembangkan sebelumnya. Pengumpulan data dilakukan dengan mengevaluasi hasil berupa pengetahun dan keterampilan tentang penyelesaian, penyusunan dan pengembangan soal HOTS. Hasil pengabdian ini berupa data skor kuantitatif dan kualitatif dan dianalisi secara deskriptif kualitatif. Adapun produk yang dihasilkan dari kegiatan pengabdian ini adalah Bank Soal Kategori HOTS yang diperoleh dari kumpulan soal-soal yang diselesaikan, disusun dan dikembangkan oleh mentee.

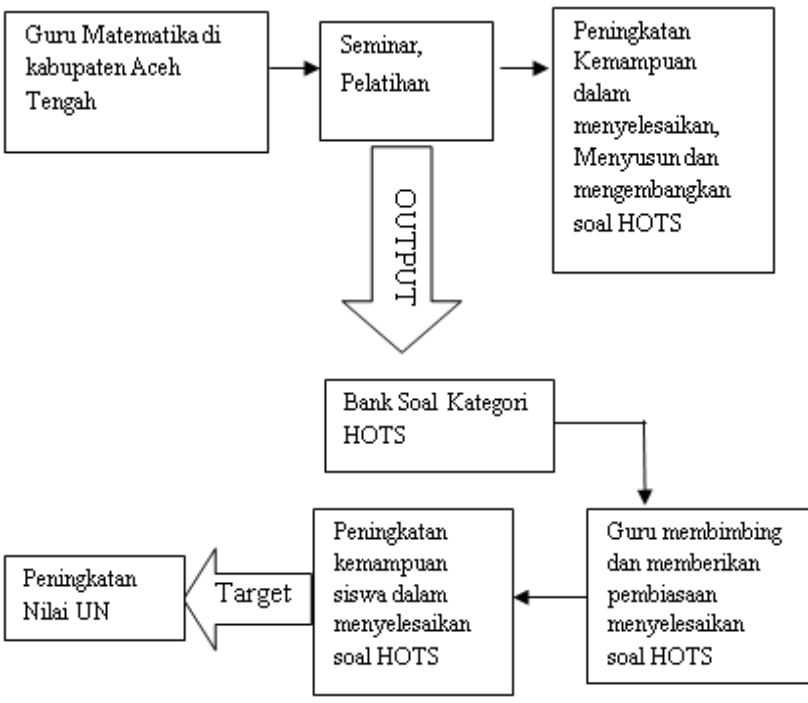

Gambar 2. Tujuan Kegiatan

Kegiatan pelatihan ini dilaksanakan selama dua hari pada tanggal 10 Juli - 11 Juli 2021 di Gedung Al Azam Takengon. Adapun susunan kegiatan yang dilaksanakan adalah sebagai berikut.

1. Maping

- Melakukan koordinasi dan diskusi dengan MGMP Matematika di kabupaten Aceh Tengah mengenai kesulitan yang dihadapi

- Melakukan kesepakatan mengenai waktu dan tempat yang sesuai untuk melakukan kegiatan.

- Mendata mentee

2. Seminar

- Melakukan tes awal untuk melihat kemampuan guru dalam penyelesaian, penyusunan dan pengembangan soal HOTS

- Melakukan pengenalan dan sosialisasi mengenai soal HOTS 
1397 Krisis UNBK: Mentoring Guru dalam Menyelesaikan, Menyusun dan Mengembangkan Soal Kategori HOTS untuk Meningkatkan Hasil Ujian Nasional Di Dataran Tinggi Gayo - Lola Mandasari, Septia Wahyuni

DOI: https://doi.org/10.31004/abdidas.v2i6.495

- Melakukan seminar mengenai teknik penyelesaian, penyusunan dan pengembangan soal HOTS

- Melakukan seminar mengenai proses belajar mengajar yang sesuai untuk megajarkan soal HOTS ke siswa

3. Mentoring

- Pelatihan

a. Melakukan latihan dan diskusi dengan mentor untuk menyelesaikan, menyusun dan mengembangkan soal HOTS

- Diskusi

a. Melakukan diskusi dan pembahasan mengenai soal-soal yang telah diselesaikan, disusun dan dikembangkan sebelumnya dalam kelompok kecil

b. Melakukan evaluasi bersama mentor dan mentee

c. Mengumpulkan semua soal yang telah diselesaikan, disusun dan dikembangkan

4. Evaluasi

- Melakukan tes kembali kepada guru setelah dilakukan pelatihan

5. Menyebarkan Output

- Memberikan Bank soal yang disusun ke sekolah-sekolah di kabupaten Aceh Tengah

\section{HASIL DAN PEMBAHASAN}

\section{Hasil Pengabdian}

a. Tahap Persiapan
1) Mempersiapkan tugas dan fungsi anggota panitia termasuk jadwal piket, dan tata tertib penyelenggaraan,

2) Mempersiapkan dan memanggil peserta pelatihan lengkap dengan kriteria peserta, waktu dan tempat penyelenggaraan serta syarat atau apa saja yang harus disiapkan dan dilakukan oleh peserta,

3) Menyiapkan formulir:

- Daftar hadir

- Data peserta

- Data narasumber

- Sertifikat;

4) Mempersiapkan dan mengirimkan surat permohonan:

- Pembawa Acara

- Nara sumber

- Penggunaan tempat : ruang dan tempat kegiatan berlangsung

- Sarana lain yang di perlukan.

5) Menyediakan perlengkapan diklat, antara lain:

- ATK

- Perlengkapan peserta

- Sarana penunjang kegiatan, seperti : OHP, LCD, White Board dan lainlain; Sound System; Transportasi.

- Spanduk

- Lokasi dan tempat : akomodasi dan konsumsi; ruang dan tempat kegiatan berlangsung.

- Sarana dokumentasi. 
1398 Krisis UNBK: Mentoring Guru dalam Menyelesaikan, Menyusun dan Mengembangkan Soal Kategori HOTS untuk Meningkatkan Hasil Ujian Nasional Di Dataran Tinggi Gayo - Lola Mandasari, Septia Wahyuni

DOI: https://doi.org/10.31004/abdidas.v2i6.495

6) Menyusun jadwal kegiatan, termasuk menentukan mentee yang akan memfasilitasinya.

7) Menyiapkan instrumen-instrumen monitoring dan teknis penilaian proses mentoring, terhadap :

- Peserta

- Mentee

- Penyelenggaraan.

8) Mempersiapkan konsumsi (snak dan makan siang) untuk peserta, narasumber dan panitia.

\section{b. Tahap Pelaksanaan}

Kegiatan mentoring ini bertujuan untuk membekali peserta dengan pengetahuan dan kemampuan teknis dalam menyelesaikan, mengembangkan dan menyususun soal matematika dengan ketegori HOTS. Sebelum acara di buka, panitia terlebih dahulu memastikan bahwa seluruh peserta sudah mengisi daftar hasir dan mendapatkan seminar kit. Kemusian, seluruh peserta diminta untuk melakukan tes awal, tes ini bertujuan untuk melihat kemampuan awal seluruh peserta dalam menyelesaikan, mengembangkan dan menyusun soal kategori HOTS sebelum mendapatkan pelatihan pada kegiatan ini.

Kegiatan ini dimulai secara resmi oleh ketua panitia. Kegiatan selanjutnya yaitu seminar materi oleh para narasumber akan dilangsungkan setelah acara pembukaan selesai. Pada kegiatan seminar ini, peserta akan diberikan pengenalan dan bekal ilmu mengenai soal HOTS oleh para narasumber. Narasumber akan memaparkan materinya masing- masing. Kemudian, selama mengikuti kegiatan mentoring (pelatihan) para peserta dibagi menjadi beberapa kelompok kecil, dan di tiap kelompok yang terdiri dari tiga atau empat peserta didampingi oleh satu mentee. Pendampingan tersebut untuk membantu dalam memahami materi dan mengerjakan tugas. Kegiatan mentoring ini didesain dengan format lokakarya.

Materi pertama yang diberikan kepada peserta adalah tentang menyusun dan mengembangkan soal HOTS. Sebelum menyusun dan mengembangkan soal, kita harus tahu terlebih dahulu perbedaan setiap level soal, seperti Lots, Mots dan Hots.

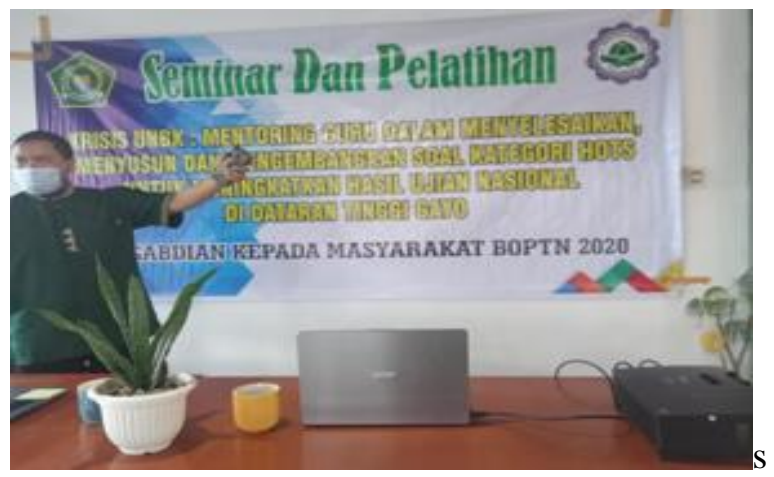

Gambar 1 Pemberian Materi HOTS

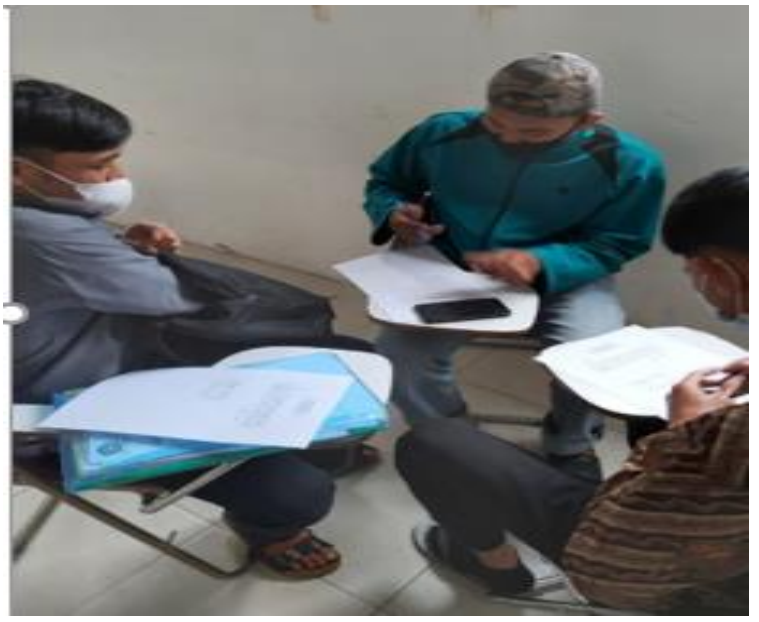

Gambar 2 Penyusunan Soal HOTS 
1399 Krisis UNBK: Mentoring Guru dalam Menyelesaikan, Menyusun dan Mengembangkan Soal Kategori HOTS untuk Meningkatkan Hasil Ujian Nasional Di Dataran Tinggi Gayo - Lola Mandasari, Septia Wahyuni

DOI: https://doi.org/10.31004/abdidas.v2i6.495

Peserta pelatihan diberikan pretest dan posttest, kemudian dilihat apakah ada peningkatan kemampuan dalam menyelesaikan soal UN berorientasi HOTS pada materi Bilangan. Skor pretest dan posttest memliki hasil yang berbeda, yang mana skor posttest lebih besar dari skor pretest yaitu rata- rata skor pretest adalah 65,81 dan rata-rata skor posttest 90,17 dari skor ideal 100. Secara lebih lengkap skor-skor peserta dapat diamati pada tabel 1 .

Dari tabel di atas tampak bahwa secara selisih peningkatan yang terjadi sebesar 24,36 dan secara $\mathrm{N}$-gain sebesar 0,71. Hal ini tampak memang terjadi adanya peningkatan. Selanjutnya akan diperlihatkan secara statistika inferensial bahwa memang benar terjadi peningkatan yang signifkan.

\section{c. Tahap Akhir}

Di akhir pelatihan, peserta diminta untuk mengumpulkan hasil kerja kelompoknya masingmasing. Hasil kerja kelompok yang diminta untuk dikumpulkan berupa soal-soal yang berhasil diselesaikan oleh setiap kelompok, soal-soal yang telah dikembangkan oleh setiap kelompok, dan soal soal yang telah susun oleh setiap kelompok, berbekal pengetahuan dan keterampilan yang diperoleh selama pelatihan. Di sesi terakhir pelatihan, setiap peserta diberi kembali lembar post tes, untuk melihat kemampuan menyelesaikan, mengembangkan dan menyusun soal HOTS akhir peserta setelah dilakukan pelatihan pada kegiatan mentoring ini. Tes ini juga bertujuan sebagai alat ukur keberhasilan kegiatan.

\begin{tabular}{|c|c|c|c|c|}
\hline \multirow[t]{3}{*}{ No } & \multirow[t]{3}{*}{ Nama } & \multicolumn{2}{|c|}{ Nilai } & \multirow[t]{3}{*}{$N$-Gain } \\
\hline & & \multicolumn{2}{|c|}{ Pretes Posttes } & \\
\hline & & $t$ & $t$ & \\
\hline 1 & $\mathrm{~T} 1$ & 30,77 & 69,23 & 0,56 \\
\hline 2 & $\mathrm{~T} 2$ & 61,54 & 92,31 & 0,80 \\
\hline & T3 & 69,23 & 92,31 & 0,75 \\
\hline & $\mathrm{T} 4$ & 76,92 & 92,31 & 0,67 \\
\hline & $\mathrm{T} 5$ & 46,15 & 92,31 & 0,86 \\
\hline & T6 & 61,54 & 92,31 & 0,80 \\
\hline & $\mathrm{T} 7$ & 69,23 & 92,31 & 0,75 \\
\hline \multirow{2}{*}{ 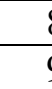 } & $\mathrm{T} 8$ & 76,92 & 84,62 & 0,33 \\
\hline & T9 & 76,92 & 92,31 & 0,67 \\
\hline & T10 & 61,54 & 84,62 & 0,60 \\
\hline 11 & T11 & 76,92 & 100 & 1,00 \\
\hline 12 & T12 & 76,92 & 92,31 & 0,67 \\
\hline 13 & $\mathrm{~T} 13$ & 69,23 & 92,31 & 0,75 \\
\hline 14 & T14 & 61,54 & 92,31 & 0,80 \\
\hline 15 & T15 & 69,23 & 92,31 & 0,75 \\
\hline 16 & T16 & 69,23 & 92,31 & 0,75 \\
\hline 17 & T17 & 69,23 & 92,31 & 0,75 \\
\hline 18 & T18 & 61,54 & 84,62 & 0,60 \\
\hline 19 & T19 & 30,77 & 69,23 & 0,56 \\
\hline 20 & $\mathrm{~T} 20$ & 61,54 & 92,31 & 0,80 \\
\hline 21 & $\mathrm{~T} 21$ & 69,23 & 92,31 & 0,75 \\
\hline 22 & $\mathrm{~T} 22$ & 76,92 & 92,31 & 0,67 \\
\hline 23 & $\mathrm{~T} 23$ & 46,15 & 92,31 & 0,86 \\
\hline 24 & $\mathrm{~T} 24$ & 61,54 & 92,31 & 0,80 \\
\hline 25 & $\mathrm{~T} 25$ & 69,23 & 92,31 & 0,75 \\
\hline 26 & $\mathrm{~T} 26$ & 76,92 & 84,62 & 0,33 \\
\hline 27 & T27 & 76,92 & 92,31 & 0,67 \\
\hline 28 & T28 & 61,54 & 84,62 & 0,60 \\
\hline 29 & T29 & 76,92 & 100 & 1,00 \\
\hline 30 & T30 & 76,92 & 92,31 & 0,67 \\
\hline 31 & T31 & 69,23 & 92,31 & 0,75 \\
\hline 32 & T32 & 61,54 & 92,31 & 0,80 \\
\hline 33 & T33 & 69,23 & 92,31 & 0,75 \\
\hline 34 & T34 & 69,23 & 92,31 & 0,75 \\
\hline 35 & T35 & 69,23 & 92,31 & 0,75 \\
\hline 36 & T36 & 61,54 & 84,62 & 0,60 \\
\hline 37 & T37 & 69,23 & 92,31 & 0,75 \\
\hline 38 & T38 & 69,23 & 92,31 & 0,75 \\
\hline 39 & T39 & 69,23 & 92,31 & 0,75 \\
\hline 40 & T40 & 61,54 & 84,62 & 0,60 \\
\hline & Jumlah & & & 12,85 \\
\hline & Rata-Rata & 65,81 & 90,17 & 0,71 \\
\hline
\end{tabular}

Tabel 1. Skor Pretest, Posttest, dan N-gain 
1400 Krisis UNBK: Mentoring Guru dalam Menyelesaikan, Menyusun dan Mengembangkan Soal Kategori HOTS untuk Meningkatkan Hasil Ujian Nasional Di Dataran Tinggi Gayo - Lola Mandasari, Septia Wahyuni

DOI: https://doi.org/10.31004/abdidas.v2i6.495

\section{Pembahasan}

Pelatihan yang dijalani guru memiliki manfaat bagi guru sebagai upaya pengembangan diri terkait pengembangan profesi (Kemendikbud, 2012). Hal ini didukung oleh Mulyawan dalam Rakib, Rombe, dan Yunus (2016) yang mengungkapkan bahwa upaya meningkatkan profesionalisme guru melalui pelatihan sangat penting dilakukan dan perlu dilakukan secara terus menerus demi tercapainya kinerja yang berkualitas bagi guru (Rakib, M., Rombe, A., \& Yunus, 2016). Sejalan dengan hasil pengabdian yang dilakukan oleh Hella Jusra dan Fitri Alyani bahwa setelh dilaksanakan pelatihan guru dapat membuat RPP kurikulum 2013 yang mengacu pada HOTS, selain itu guru dapat membuat instrument HOTS matematika (Alyani, 2021).

Pelatihan dalam penyusunan soal HOTS matematika sangat bermanfaat dalam pengembangan keilmuan guru dalam menyelesaikan serta Menyusun soal kategori HOTS, dari hasil evaluasi yang dilakukan oleh tim pengabdian menunjukkan peningkatan pemahaman guru dalam penyelesaian dan penyusunan soal kategori HOTS. Seperti hasil pengabdian yang dilakukan oleh Imelda Darmayanti Manurung dkk bahwa kegiatan pelatihan penyusunan soal HOTS (Higher Order Thinking Skills) bagi guru- guru madrasah ibtidaiyah ini dapat menambah pengetahuan dan pemahaman guru tentang bagaimana menyusun dan menulis soal berbasis pada keterampilan berpikir tingkat tinggi sesuai secara dengan tahapan-tahapan berdasarkan pedoman penulisan soal HOTS sehingga mereka mampu dan terampil dalam menyusun soal tertulis sesuai dengan tingkatan kelas yang mereka ampu terutama dalam ranah kognitif. Pendampingan dan pembinaan lebih lanjut juga diperlukan dalam menyusun soal untuk mengukur keterampilan afektif dan psikomotorik (Manurung, 2021).

\section{SIMPULAN}

Kesimpulan dari pengabdian ini adalah para guru peserta mentoring guru dalam menyelesaikan, menyusun dan mengembangkan soal kategori HOTS untuk meningkatkan hasil ujian nasional di dataran tinggi gayo yang berjumlah 40 orang dari berbagai sekolah yang mendapat nilai UNBK dibawah nilai rata-rata UN Kabupaten Aceh Tengah, memiliki peningkatan kemampuan menyelesaikan soal UN berorientasi HOTS. Level peningkatannya berada pada kriteria tinggi. Dengan demikian peneltian ini dapat memberikan rekomendasi bahwa pelatihan sejenis ini dapat dilaksanakan secara rutin bagi guru-guru Matematika SMA/MA lain dari Kabupaten diluar Aceh Tengah.

\section{DAFTAR PUSTAKA}

Alyani, H. J. dan F. (2021). Pelatihan untuk GuruGuru SD dalam Membuat Instrumen HOTs Mata Pelajaran Matematika. E-DIMAS: Jurnal Pengabdian Kepada Masyarakat, 12(1), 167.

EFFENDY, M. (n.d.). KEMENDIKBUD SUSUN SOAL UN 2018 DENGAN INSTRUMEN HOTS

https://www.republika.co.id/berita/nasional/u mum/18/04/02/p6jwfu359-kemendikbudsusun-soal-un-2018-dengan-instrumen-hots (diakses 5 agustus 2019).

Manurung, I. D. (2021). Pelatihan Penyusunan 
1401 Krisis UNBK: Mentoring Guru dalam Menyelesaikan, Menyusun dan Mengembangkan Soal Kategori HOTS untuk Meningkatkan Hasil Ujian Nasional Di Dataran Tinggi Gayo - Lola Mandasari, Septia Wahyuni

DOI: https://doi.org/10.31004/abdidas.v2i6.495

Soal HOTS (Higher Order Thinking Skills) bagi Guru-Guru Madrasah Ibtidaiyah. PRODIKMAS Jurnal Hasil Pengabdian Kepada Masyarakat E-ISSN2580-3069 Dan p-ISSN: 2548-6349, Volume 6(Nomor 1).

Muhammad, H. (2019). Peserta UN Keluhkan Soal HOTS Ini Bantahan Kemendikbud. https://www.republika.co.id/berita/pendidika n/eduaction/18/04/23/p7mumw409-pesertaun-keluhkan-soal-hots-ini-bantahankemendikbud (diakses 5 agustus 2019)

Pendidikan, B. S. N. (2018). BSNP rilis Kisi Kisi USBN dan UN 2019. http://bsnpindonesia.org/2018/11/27/bsnp-rilis-kisi-kisiusbn-dan-un-2019/ (diakses 25 Juli 2019)

Rakib, M., Rombe, A., \& Yunus, M. (2016). Pengaruh pelatihan dan pengalaman mengajar terhadap profesionalisme guru. Ad'ministrare, 3-2, 137-148.

Shihab, N. (2019). 70\% Anak Indonesia Tak Maтри Jawab Soal Hots. https://www.medcom.id/pendidikan/newspendidikan/ObzdB0gK-70-anak-indonesiatak-mampu-jawab-soal-hots (diakses 10 Agustus 2019)

Suprayitno, T. (2019a). 40 Persen Siswa Kesulitan Jawab Soal HOTS. https://www.antaranews.com/berita/708147/k emendikbud-40-persen-siswa-kesulitanjawab-soal-hots (diakses 10 Agustus 2019)

Suprayitno, T. (2019b). Soal Ujian Nasional Tahun Mendatang Akan Didominasi HOTS. http://disdik.jabarprov.go.id/news/1143/soalujian-nasional-tahun-mendatang-akandidominasi-hots (diakses 5 agustus 2019)

Suprayitno, T. (2019c). Tingkat Kesulitan Soal UN 2019 Tidak Berubah Ini Komposisin Soalnya. https://www.kemdikbud.go.id/main/blog/201 9/03/tingkat-kesulitan-soal-un-2019-tidakberubah-ini-komposisi-soalnya (diakses 5 Agustus 2019)

Wikipedia. (2019). Ujian Nasional. https://id.wikipedia.org/wiki/Ujian_Nasional (diakses 25 Juli 2019) 